навчальному матеріалі. Передусім ідеться про ідеї елементарності, принципи збереження, симетрії. Посилення тенденцій до інтеграції в сучасному суспільстві висуває на чільне місце ідею єдності наукової картини світу, де комп'ютерні вміння відіграють провідну роль.

3 огляду на це використання ІКТ у навчальному процесі надає змогу педагогу під час занять акцентувати увагу на стимулюванні процесів саморозвитку, самореалізації й самоосвіти студентів. Ефективність заняття підвищується тоді, коли студенти повністю залучені до роботи. Цього можна досягти лише за умови розумного використання IKT.

На основі аналізу програм (навчальних, робочих), кваліфікаційних характеристик, навчальних планів i представленої моделі підготовки вчителя технологій можна стверджувати, що сучасна система навчання потребує докорінного перегляду. Такі зміни повинні бути спрямовані на досягнення однієї мети підготувати інтелектуального фахівця, який відповідає сучасним вимогам. Тому якість підготовки кваліфікованих спеціалістів є тією передумовою, яка має суттєвий уплив на подальший розвиток народної освіти в державі.

Перспективами подальших розвідок $\epsilon$ розроблення системи підготовки майбутніх учителів технологій до професійної діяльності 3 урахуванням сучасних тенденцій розвитку суспільства.

\title{
Література
}

1. Горбатюк Р. М. Проблеми автоматизації освітнього процесу / Р. М. Горбатюк // Проблеми педагогічних технологій : зб. наук. праць Волинського держ. ун-ту ім. Лесі Українки. - Луцьк, 2006. - Вип. 2-4 (31-33). - С. 356-362. 2. Горбатюк Р. М. Формування комп'ютерної культури в майбутніх інженерів-педагогів на основі інтеграції психологопедагогічної і фахової підготовки / Р. М. Горбатюк// Наукові записки Тернопільського нац. пед. ун-ту ім. В. Гнатюка. Серія : Педагогіка. - Тернопіль, 2009. - № 1. - С. 157-163. 3. Романишина Л. М. Інноваційні технології в підготовці майбутніх фахівців/ Л. М. Романишина, О. Я. Романишина // Збірник наукових праць Кременецького обл. гуманітар. пед. ін.-ту ім. Т. Шевченка. Серія : Педагогічні науки. - Кременець, 2007. Вип. 2. - С. 50-57. 4. Романишина Л. М. Сучасні педагогічні технології підготовки майбутніх фахівців / Л. М. Романишина // Проблеми освіти; спец. випуск. - К. : Вид-во наук.-метод. центру вищої освіти, 2006. - С. 140-147. 5. Шеннон Г. Р. Имитационное моделирование систем - искусство и наука: [пер. с англ.] / Г.Р.Шеннон; под ред. Е. К. Масловского. - М. : Мир, 1978. - 418 с. б. Веселовська Г. В. Основи комп'ютерної графіки : [навч. посіб.] / Г. В. Веселовська. - К. : Центр навч. літ-ри, 2004. 392 c.

\section{НАЙВАЖЛИВІШ АСПЕКТИ МОВНОЇ ПІДГОТОВКИ СТУДЕНТІВ ЛІСОТЕХНІЧНОГО НАПРЯМУ НАВЧАННЯ}

Гриджук О. С. Найважливіші аспекти мовної підготовки студентів лісотехнічного напряму навчання.

У статті обгрунтовано доцільність поглиблення мовної підготовки студентів лісотехнічного ВН3; окреслено основні аспекти цього процесу (термінологічний, лексикографічний, граматико-стилістичний, фахово-прикладний); визначено способи опрацювання термінологічної лексики лісівництва та деревообробки. 
Ключові слова: мовна підготовка, аспекти мовної освіти, мовні норми, фахова термінологія, термін.

Гриджук О. Е. Наиболее важные аспекты языковой подготовки студентов лесотехнического направления обучения.

В статье обоснована целесообразность углубления языковой подготовки студентов лесотехнического вуза; обозначены основные аспекты этого процесса (терминологический, лексикографический, грамматико-стилистический, профессионально-прикладной); определены способы изучение терминологической лексики лесоводства и деревообработки.

Ключевые слова: языковая подготовка, аспекты языкового образования, речевые нормы, профессиональная терминология, термин.

Hrydzhuk O. The most important aspects of language learning of the students of the Forestry training direction.

In the article the feasibility of deepening the language training of the students of the Forestry University is substantiated; the main aspects of this process (terminologycal, lexicographic, grammar and stylistic, professionally-applied) are described; the ways of processing forestry and woodworking terminology are identif ied.

Key words: language training, aspects of language education, linguistic norms, professional terminology, the term.

Потреби суспільства вимагають принципово нового змісту та цілей освіти: лише якісне навчання студентів зумовить їх конкурентоспроможність на сучасному ринку праці. В умовах соціально-економічних реформ сьогодення завданням вищої школи $\epsilon$ підготовка фахівців, рівень професіоналізму яких визначається сукупністю набутих професійних знань і навичок, умінням грамотно й аргументовано висловлюватися, здійснюючи в такий спосіб науково-виробниче і службове спілкування. Досконале володіння українською мовою стає необхідним компонентом професійної підготовки спеціалістів різного профілю.

Mema cmammi- розкрити основні аспекти мовної підготовки студентів майбутніх фахівців лісопромислового комплексу.

Окреслена проблема набуває актуальності в сучасних науково-методичних розвідках. Формуванню мовно-комунікативної компетентності студентів присвячені праці О. Горошкіної, Л. Знікіної, К. Климової, Л. Мамчур, Л. Мацько, Н. Остапенко, О. Селіванової, Т. Симоненко. Проблему розвитку навичок українського професійного мовлення студентів досліджували Н. Артикуца, І. Дроздова, О. Ковтун, О. Мірошниченко, В. Пасинок. У навчальний процес вищих навчальних закладів України введено нові професійно орієнтовані дисципліни, як-от: «Основи термінознавства» (Національний університет «Львівська політехніка» та Міжрегіональна академія управління персоналом), «Соціально-економіко-географічна термінологія» (Львівський національний університет ім. І. Франка), «Мова права», «Правнича лінгвістика» (Національний університет «Києво-Могилянська академія»), «Культура професійного мовлення», «Правнича лінгвістика» (Національна академія внутрішніх справ).

Важливим науково-методичним завданням $\epsilon$ пошук ефективних способів формування мовно-комунікативної компетентності студентів загалом, особливо це стосується студентів вищих технічних навчальних закладів, у яких рівень мовної підготовки значно нижчий, аніж у представників гуманітарних спеціальностей. 
Сучасні технології навчання роблять головний акцент на засвоєнні спеціальних дисциплін, що, 3 одного боку, безперечно $є$ правильним, а 3 іншого,- зменшує значущість гуманітарної підготовки студентів.

Поглиблення лінгвістичної підготовки студентів лісотехнічних спеціальностей може відбуватися через розроблення й упровадження в навчальний процес нових навчальних курсів, зокрема: «Фахова термінологія», «Культура наукової та фахової мови», «Основи риторики», «Робота з науковим текстом». Обмеження цього процесу через розширення системи практичних завдань та збільшення обсягу самостійної роботи студентів у дисципліні «Українська мова за професійним спрямуванням» вочевидь є недостатнім.

Розуміння необхідності говорити правильно має стати наскрізним у процесі навчання у вищому навчальному закладі, проте таке розуміння не зводиться лише до дотримання мовних норм на всіх рівнях, воно стосується і знання способів передання інформації, умілого аргументування чи апелювання опонентові, правильності побудови і проголошення наукового тексту, його стилістики, оперування фаховою термінологією.

Мовна підготовка $є$ частиною гуманітарного циклу навчання, іiі, на наш погляд, доречно поєднати зі спеціальною, об'єднавши зусилля філологів і фахівців зі спеціальних дисциплін, і запропонувати студентам аналіз фахової термінології як об'єкта філологічної науки та засобу практичної реалізації набутих знань у сфері майбутньої наукової та професійної діяльності.

Рівень мовних і комунікативних навичок визначається багатьма чинниками, серед яких одним із найвагоміших є опанування спеціальною термінологією (належне iii засвоєння і правильне використання в майбутній професійній діяльності). «Оскільки мова професійного спілкування $\epsilon$ соціально зумовленим варіантом сучасної літературної мови, то професіонал має досконало володіти понятійно-категоріальним апаратом певної сфери діяльності і відповідною йому системою термінів» [4, c. 257].

Під час вивчення спеціальних дисциплін здебільшого не приділяється увага правильності вживання самих термінів, специфіці їх уживання в синтаксичній конструкції. Тому особливої актуальності набуває розроблення спеціальних технологій і методик роботи з фаховою лексикою (уведення терміна в науковий текст, розрізнення його семантики, максимальної точності у вживанні, розуміння особливостей перекладу, фіксації у словнику) i використання 3 цією метою різноманітних методів навчання (пояснювально-ілюстративного, репродуктивного, проблемного, частково-пошукового, дослідницького) [5, с. 126].

У сучасних наукових дослідженнях найголовнішими аспектами (підходами) мовної освіти студентів уважають термінологічний, лексикографічний, граматикостилістичний, фахово-прикладний [2]. Застосування таких підходів для професійно спрямованої лінгвістичної підготовки студентів лісотехнічних спеціальностей, на наш погляд, є доречним, оскільки тоді у процесі навчання максимально буде враховано наукові та професійні потреби майбутнього фахівця лісопромислового комплексу.

Термінологічний аспект передбачає не лише належне засвоєння термінології фаху як цілісної організованої системи, диференціації значень терміна, розуміння лексикосемантичних процесів (явища синонімії, антонімії, омонімії), специфіки функціонування питомих і запозичених термінів, а й системне вивчення термінів суміжних спеціальностей (наприклад, лісівництва, садово-паркового господарства, технології деревообробки), оскільки робота в галузі лісового господарства поєднує різні напрямки діяльності - лісове та мисливське господарства, лісокористування, лісопромислове виробництво, 
деревооброблення тощо. Крім того, навіть у межах одного виробництва (наприклад, на деревооброблювальному комбінаті) необхідним $\epsilon$ принаймні знання видів i сортів деревини, а також вад деревної сировини, що визначають ії якість, а отже, слід уміти кваліфіковано пояснювати основні технологічні процеси, що відбуваються на виробництві, застосовуючи професійну термінологію.

Аналіз термінів лісівництва та деревообробки доцільно здійснювати як у синхронічному, так i в діахронічному аспектах. Вивчення процесу розвитку терміносистеми фаху не лише забезпечить розуміння витоків ії становлення, дасть змогу прослідкувати розвиток чи зміну семантики термінів, описати їх словотвірні моделі, а й ознайомить студентів із постатями дослідників-лісівників, їх науковим доробком, першими працями 3 питань лісівництва, написаних українською мовою.

Як зазначає Н. Артикуца, «лексико-семантичний підхід тісно пов’язаний із стилістичним та граматичним підходами, адже в діловому мовленні вибір слова повинен відповідати не тільки вимогам семантичної точності, але й стилістичної доречності, граматичної та стилістично правильної сполучуваності» [2].

Робота над граматичними помилками може здійснюватися через опрацювання фахових наукових текстів (передусім це завдання на редагування та переклад). Доречним є також аналіз типових порушень граматичних і стилістичних норм у процесі аудиторного спілкування (виступ на семінарі, доповідь, обговорення проблемних ситуацій), взаємоперевірка підготовлених есе, творів-роздумів, складених зразків документів.

Використання стилістичного аспекту зумовлене, з одного боку, необхідністю засвоєння норм літературної мови щодо слововживання, усвідомленням доречності використання тих чи тих мовних засобів залежно від стилю висловлювання, а 3 іншого, - урахуванням специфіки майбутньої роботи (маємо на увазі регіон країни), де можливим стає вживання діалектних найменувань спеціальних понять (наприклад, флори і фауни України).

Доцільність застосування лексикографічного підходу до вивчення термінології лісівництва та деревооброблення вбачаємо у формуванні навичок послугування фаховими словниками в наукових та виробничих потребах. Сучасний інженер лісопромислового комплексу може здійснювати пошук необхідної інформації в різних типах словників - від енциклопедичних до спеціалізованих. Тому важливим $\epsilon$ ознайомлення студентів із фаховою лексикографічною літературою, що сприятиме поглибленому засвоєнню термінологічної лексики, варіантних термінів, складних терміносполук. Окрім цього, робота на заняттях із різними типами загальних, галузевих і лінгвістичних словників дозволить студентові зрозуміти специфіку змістового наповнення й оформлення словникової статті, а отже, усвідомити доцільність використання того чи іншого виду словника в майбутній професійній діяльності. Укладання невеликих за обсягом термінологічних словників (наприклад, багатозначних термінів, термінів-синонімів, термінів-словосполучень тощо) здійснюється задля більш досконалого опанування студентами складних аспектів термінологічних систем лісівництва та деревооброблення.

Фахово-прикладний аспект передбачає роботу з різними жанрами наукового тексту (написання тез, статті, підготовка доповіді, оформлення курсової, бакалаврської роботи), спеціалізованих документів, формує навички усвідомленого вибору мовних засобів залежно від змісту й мети висловлювання, правильного й точного використання термінів, навчає способам опрацювання наукової літератури. Загалом «методу розвитку професійного мовлення властиві прийоми опрацювання граматичних форм, добір формул мовленнєвого ділового етикету, відбір 
паралінгвістичних чинників, правил поведінки фахівця, урахування професійної ситуації спілкування тощо» [4, с. 171].

Використання всіх зазначених аспектів у процесі мовної підготовки студентів лісотехнічного напряму навчання забезпечить належний рівень фахових лінгвістичних знань, що сприятиме успішності в майбутній професійній діяльності.

Отже, дослідження найважливіших аспектів мовної підготовки студентів лісотехнічного напряму навчання, аналіз навчальних програм, а також результати анкетування студентів обгрунтовують доцільність розвитку й удосконалення термінологічної компетентності, що дозволяє зробити висновок про необхідність створення методики навчання фахової термінології, упровадження якої в навчальний процес підвищить якість професійної компетентності майбутніх інженерів лісотехнічної та деревообробної галузей і сприятиме розвитку їх мотивації у навчанні української мови як засобу ділової комунікації.

\section{Література}

1. Артикуца Н. В. Мова права i юридична термінологія : [навч. посіб.] [Електронний ресурс] / Н. В. Артикуца. - К. : Стилос, 2004. - Режим доступу до докум. : http://en.kul.kiev.ua/ praci-2004-roku/artikuca-n.-v.-mova-prava-i-juridichnaterminologija-navchalniy-posibnik.html 2. Артикуца Н. В. Про нові підходи до мовної підготовки майбутніх юристів і викладачів права у вищих навчальних закладах України : препринт [Електронний ресурс]/ Н. В. Артикуца. - Режим доступу до докум. : $\quad$ http://www.ekmair.ukma.kiev.ua/handle/123456789/2456 3. Булик-

Верхола С. 3. Основи термінознавства : [навч. посіб.] / С. З. Булик-Верхола, Г. В. Наконечна, Ю. В. Теглівець. - Львів : Видавництво Львівської політехніки, 2013. - 160 с. 4. Дроздова І. П. Наукові основи формування українського професійного мовлення студентів нефілологічних факультетів ВНЗ : [монографія] / І. П. Дроздова ; Харк. нац. акад. міськ. госп-ва. - Х. : ХНАМГ, 2010. - 320 с. 5. Кочан І. М. Словникдовідник з методики викладання української мови / І. М. Кочан, Н. М. Захлюпана. - [2-е вид., випр. і доп.]. - Львів : Видавничий центр ЛНУ ім. Івана Франка, 2005. - 306 с. 6. Полковенко Т. В. Навчальна програма дисципліни «Основи термінознавства» (для бакалаврів) [Електронний ресурс] / Т. В. Полковенко. - К. : МАУП, 2009. - 26 с. - Режим доступу до докум. : http://library.iapm.edu.ua/ metod_disc/Pdf/4195_osn_temin.pdf

$$
\text { УДК 378:37.011.3-051]:5 }
$$

Олена Лаврентьєва

\section{МЕТОДИКА РОЗВИТКУ МЕТОДОЛОГІЧНОЇ КУЛЬТУРИ МАЙБУТНІХ УЧИТЕЛІВ ПРИРОДНИЧИХ ДИСЦИПЛІН У ПРОЦЕСІ ПРОФЕСІЙНОЇ ПІДГОТОВКИ}

Лаврентьєва О. О. Методика розвитку методологічної культури майбутніх учителів природничих дисциплін у процесі професійної підготовки.

У статті розкрито основні концептуальні положення методики розвитку методологічної культури майбутнього вчителя природничих дисциплін. Методику представлено як упорядковану сукупність алгоритмів, процедур, етапів, комплексу педагогічних умов, форм, засобів і прийомів, форм і видів професійно-педагогічної підготовки, що спрямовуються на наскрізну загальну та спеціальну методологічну підготовку й цілеспрямований розвиток у майбутнього вчителя методологічної культури.

Ключові слова: методика, професійна підготовка вчителя природничих 